\title{
LONG-TERM RESULTS OF HIP ARTHROPLASTY FOR FAILURE OF PREVIOUS SURGERY
}

\author{
A. ECHEVERRI, P. SHELLEY, B. M. WROBLEWSKI
}

From the Centre for Hip Surgery, Wrightington

\begin{abstract}
We report a retrospective review of 127 low friction arthroplasties carried out for the failure of a previous hip operation. After an average follow-up of 10.4 years, $20 \%$ of cases required further revision, over half of them for deep infection. We estimated from the radiographic appearances that eventual failure by loosening was probable in $58 \%$ on the femoral side and $56 \%$ on the acetabular side of the arthroplasties.
\end{abstract}

The early results of the Charnley low friction arthroplasty (LFA) carried out after the failure of previous hip surgery have been reported (Dupont and Charnley 1972). The incidence of early complications was similar to that in other series of primary hip replacements carried out in the same unit, except that the incidence of deep sepsis was higher at $3.7 \%$.

We now present the long-term results of LFAs carried out for the failure of a previous hip operation, giving special emphasis to complications requiring further revision and to the detailed analysis of radiographic appearances which may indicate the likelihood of later complications.

\section{MATERIAL AND METHODS}

Between November 1962 and December 1969, a total of 3589 LFAs were carried out at Wrightington. Among these were 310 patients who had 329 LFAs performed for failure of previous operations on the hip. Of these 310 patients, 191 were excluded from this review: 68 had died within six years of the LFA (none had needed a second revision) while 123 had been followed up for less than six years or had been lost to follow-up. The remaining 119 patients (127 hips) had a minimum follow-up of six years, unless a second revision had been needed before this. Antibiotic-loaded acrylic cement was

A. Echeverri, MD, Orthopaedic Registrar Carrera 24 C-bis No. 8-31 oeste, Cali, Colombia, South America.

P. Shelley, PhD, Research Fellow

B. M. Wroblewski, FRCS, Consultant Orthopaedic Surgeon Centre for Hip Surgery, Wrightington Hospital, Nr. Wigan, Lancashire WN6 9EP, England.

Requests for reprints should be sent to Mr B. M. Wroblewski. (C) 1988 British Editorial Society of Bone and Joint Surgery $0301-620 \mathrm{X} / 88 / 1023 \$ 2.00$

J Bone Joint Surg [Br] 1988;70-B:49-51
Table I. Previous operations in 127 hips revised to an LFA

\begin{tabular}{|c|c|c|}
\hline & Number & Per cent \\
\hline Intertrochanteric osteotomy & 72 & 57 \\
\hline $\begin{array}{l}\text { Femoral head replacement } \\
\text { Moore or Thompson } \\
\text { Judet }\end{array}$ & $\begin{array}{r}21 \\
6\end{array}$ & 21 \\
\hline Cup arthroplasty & 13 & 10 \\
\hline Total hip arthroplasty & 5 & 4 \\
\hline $\begin{array}{l}\text { Fracture fixation } \\
\text { Pseudarthrosis } \\
\text { Stabilisation by central dislocation } \\
\text { Unspecified }\end{array}$ & $\left.\begin{array}{l}4 \\
3 \\
2 \\
1\end{array}\right\}$ & 8 \\
\hline
\end{tabular}

not used and systemic antibiotics were not given routinely.

Clinical results were assessed from the records and were based on the Charnley (1972) modification of the d'Aubigné and Postel scale (1954). Radiographic assessment was by the review of the available serial films. All the measurements on the femoral side of the LFA were made directly on the radiographs (Loudon and Charnley 1980). The appearances of the bone-cement junction on the acetabular side were assessed according to Hodgkinson, Shelley and Wroblewski (1987).

\section{RESULTS}

Of the 119 patients, 29 were men and 90 were women. Their average age at the time of their first hip operation was 54.8 years (range 18 to 77.7 years) while at revision to an LFA it was 59.5 years (range 23.8 to 79.3 years). The original diagnosis was primary osteoarthritis in 91 patients $(72 \%)$, secondary osteoarthritis in $22(17 \%)$ and rheumatoid arthritis in six $(5 \%)$. The previous hip operations are listed in Table I. Only in four of the cases of intertrochanteric osteotomy was the fixation device removed at a separate operation, before the LFA. 
The average follow-up for the whole group was 10.4 years (range 6 to 23.1 years) with 11.2 years (range 6.1 to 23.1 years) for the patients who have not required a second revision.

Bacteriological swabs were taken at the LFA in 25 cases only; results were negative in 20 and positive in five. Three were positive for Staphylocorcus aureus (all developing deep sepsis), one for $E$. coli and one for diphtheroids. The results of radiographic assessment of acetabular fixation are given in Table II, and for the femoral component in Table III. In 13 cases stem subsidence could not be accurately measured because the radiographs were not comparable.

Second revision. Of the whole group of 127 hips, 26 $(20.5 \%)$ had a further revision an average of 7.1 years after the LFA (range 0.6 to 14.7 years). The indications for these third operations are given in Table IV; no relationship was found with the type of the original hip operation except that the second revision rate was $30 \%$ in the combined group of those who originally had femoral endoprostheses (21 hips) or total hip arthroplasties (five hips).

Of the 15 cases of deep sepsis, eight were converted to a pseudarthrosis, while seven had a successful onestage exchange operation. In two cases revised for pain no abnormality was found. One case of recurrent dislocation was treated successfully by reattachment of the greater trochanter. For the cases with mechanical loosening of the components or fracture of the femoral stem the components were changed.

\section{DISCUSSION}

The long-term follow-up of LFA carried out for failures of previous hip surgery shows an incidence of deep sepsis of $11.8 \%$ as compared with $3.7 \%$ at short-term review (Dupont and Charnley 1972). Although routine bacteriology was not performed in the earlier cases it is now obvious that it is indicated for all cases which have had previous hip operations. It is also suggested that removal of any metallic device should be performed as a separate previous operation, provided that it can be carried out safely. There is also little doubt that, in such cases, antibiotics in the acrylic cement (Lynch et al. 1987), or systemically, or both, are indicated.

Apart from the high incidence of deep sepsis and excluding the three cases of fractured femoral stem $(2.4 \%)$, the secondary revision rate of $7.3 \%$ is not particularly high considering both the quality of the original bone stock and the stage of evolution of the Charnley LFA at the time of the first revision. However, detailed examination of the radiographic appearances leave no room for complacency. Progressive stem subsidence may well indicate eventual failure, and this was present in $43 \%$ of the cases which followed intertrochanteric osteotomy and in $50 \%$ of all the other
Table II. Radiographic appearance of the bone-cement junction at the acetabulum

\begin{tabular}{|c|c|c|c|c|c|}
\hline \multirow[b]{2}{*}{ Type } & & \multicolumn{2}{|c|}{ Width of gap } & \multirow[b]{2}{*}{ Number } & \multirow[b]{2}{*}{ Per cent } \\
\hline & & $<1 \mathrm{~mm}$ & $>1 \mathrm{~mm}$ & & \\
\hline 0 & No demarcation & & & 19 & 15 \\
\hline 1 & $\begin{array}{l}\text { Demarcation in outer } \\
\text { third only }\end{array}$ & 34 & 1 & 35 & 27.5 \\
\hline 2 & $\begin{array}{l}\text { Demarcation in outer and } \\
\text { middle thirds }\end{array}$ & 8 & $\mathbf{0}$ & 8 & 6.3 \\
\hline 3 & Complete demarcation & 13 & 33 & 46 & 36.2 \\
\hline 4 & Migration of socket & & & 17 & 13.4 \\
\hline & Inadequate radiographs & & & 2 & \\
\hline
\end{tabular}

Table III. Radiographic appearance of the femoral component

\begin{tabular}{lll}
\hline & Number & Per cent \\
\hline Unchanged & 54 & 43 \\
Subsidence > $1.6 \mathrm{~mm}$ & 53 & 46 \\
$\begin{array}{l}\text { Fracture of cement } \\
\quad \text { Tip } \\
\text { Other }\end{array}$ & 14 & 13 \\
$\begin{array}{l}\text { Endosteal cavitation } \\
\begin{array}{l}\text { Bone-cement demarcation } \\
\text { General } \\
\quad \text { Proximal } \\
\text { Distal }\end{array}\end{array}$ & 3 & 12 \\
\hline
\end{tabular}

Table IV. Indications for revision of the LFA

\begin{tabular}{lcc}
\hline & Number & Per cent \\
\hline Infection & 15 & 11.8 \\
Mechanical loosening & 4 & 3.1 \\
Fractured stem & 3 & 2.4 \\
Unexplained pain & 2 & 1.6 \\
Dislocation & 1 & 0.8 \\
Fractured femur & 1 & 0.8 \\
\hline
\end{tabular}

groups combined. If endosteal cavitation and demarcation of the femoral cement are also considered as signs of incipient failure, then the likelihood of further revision of the femoral stem increases to $58 \%$. As regards the acetabular side, only $15 \%$ of hips showed no demarcation at the bone-cement junction and $27.5 \%$ showed demarcation of the outer third only. Excluding two cases in which radiographs were inadequate $55.9 \%$ of cases showed either demarcation of the outer two-thirds, complete demarcation, or migration of the socket. The majority of these must be regarded as being at risk for 
loosening (Hodgkinson et al. 1987), although not as yet in need of revision for asymptomatic failure.

The clinical results of an LFA carried out for the failure of a previous hip operation remain satisfactory, but this success must be balanced against the high incidence of deep sepsis and the likelihood of a rising revision rate for mechanical loosening with increasing follow-up. It must also be emphasised that clinical function does not necessarily represent the mechanical state of the arthroplasty, especially with regard to the acetabulum.

Surgeons who undertake uncemented total hip arthroplasty and expect to be able to perform an easy revision to a cemented replacement may be rewarded by short-term success but are likely to be disappointed by a high incidence of long-term failure.

\section{REFERENCES}

Charnley J. The long-term results of low friction arthroplasty of the hip performed as a primary intervention. $J$ Bone Joint Surg [Br] 1972;54-B :61-76.

Dupont JA, Chamley J. Low-friction arthroplasty of the hip for the failures of previous operations. J Bone Joint Surg [Br] 1972;54-B:77-87.

Hodgkinson JP, Shelley P, Wroblewski BM. The correlation between the radiographic appearance and operative findings at the bonecement junction of the socket in Charnley low friction arthroplasties. Clin Orthop 1987; in press.

Loudon JR, Charnley J. Subsidence of the femoral prosthesis in total hip replacement in relation to the design of the stem. J Bone Joint Surg $[\mathrm{Br}] 1980 ; 62-\mathrm{B}: 450-453$.

Lynch M, Esser MP, Shelley P, Wroblewski BM. Deep infection in Charnley low-friction arthroplasty: comparison of plain and gentamicin-loaded cement. J Bone Joint Surg [Br] 1987; 69-B:355-60.

Merle d'Aubigne R, Postel M. Functional results of hip arthroplasty with acrylic prosthesis. J Bone Joint Surg [Am] 1954;36-A :451-75. 